\title{
Archival Investigation of the Pyron Homestead (41BX278), New City Block 7657, San Antonio, Texas
}

I. Waynne Cox

Center for Archaeological Research

Follow this and additional works at: https://scholarworks.sfasu.edu/ita

Part of the American Material Culture Commons, Archaeological Anthropology Commons, Environmental Studies Commons, Other American Studies Commons, Other Arts and Humanities Commons, Other History of Art, Architecture, and Archaeology Commons, and the United States History Commons

Tell us how this article helped you.

This Article is brought to you for free and open access by the Center for Regional Heritage Research at SFA ScholarWorks. It has been accepted for inclusion in Index of Texas Archaeology: Open Access Gray Literature from the Lone Star State by an authorized editor of SFA ScholarWorks. For more information, please contact cdsscholarworks@sfasu.edu. 
Archival Investigation of the Pyron Homestead (41BX278), New City Block 7657, San Antonio, Texas

\section{Creative Commons License}

(c) (i) (8)

This work is licensed under a Creative Commons Attribution-NonCommercial 4.0 International License 


\section{ARCHIVAL INVESTIGATION OF THE PYRON HOMESTEAD (41 BX 278), NEW CITY BLOCK 7657, SAN ANTONIO, TEXAS}

I. Waynne Cox

Center for Archaeological Research The University of Texas at San Antonio Archaeological Survey Report No. 210 



\title{
ARCHIVAL INVESTIGATION OF THE PYRON HOMESTEAD (41 BX 278), NEW CITY BLOCK 7657, SAN ANTONIO, TEXAS
}

\author{
I. Waynne Cox
}

Center For Archaeological Research The University Of Texas at San Antonio(B Archaeological Survey Report No.210 
A list of publications by the Center for Archaeological Research can be obtained by sending $\$ 1.00$ to the Center for Archaeological Research, The University of Texas at San Antonio, San Antonio, Texas 782490658. 


\begin{abstract}
The Center for Archaeological Research, The University of Texas at San Antonio, conducted an archival investigation on a portion of New City Block 7657 in southeast San Antonio for the Texas Trust Savings Bank of Marble Falls, Texas. The property contained the site of the historic Pyron House and thought to possibly also contain the buried remains of the San José acequia. The study revealed that the homestead was probably constructed in 1849, and although recently destroyed, the foundation remains in the ground. The research further revealed that the acequia did not pass through the property under study, but instead is located further to the west on the other side of Mission Road.
\end{abstract}




\section{TABLE OF CONTENTS}

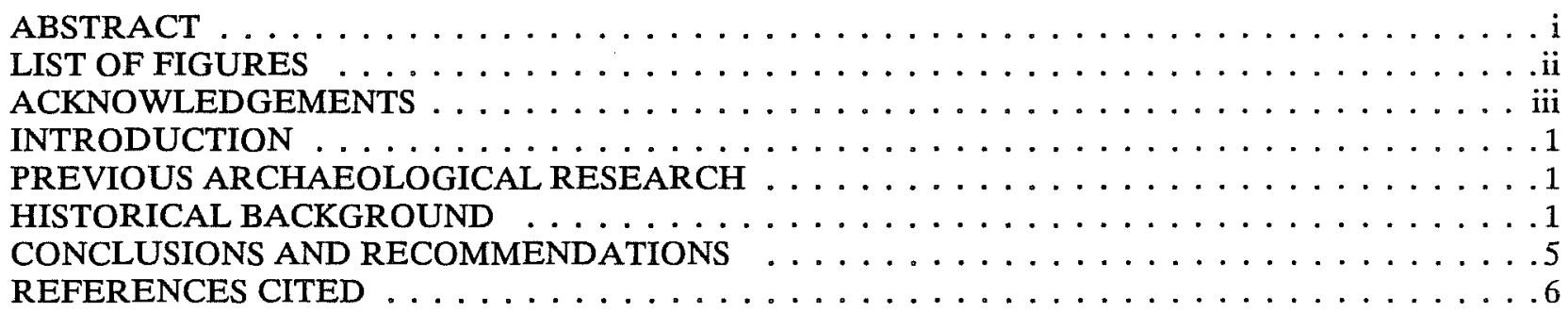

\section{LIST OF FIGURES}

1. Location of the Pyron Homestead and the San José Acequia $\ldots \ldots \ldots \ldots \ldots \ldots \ldots \ldots$

2. Charles Lynn Pyron . . . . . . . . . . . . . . . . . . . . . . . . . . 


\section{ACKNOWLEDGEMENTS}

We wish to thank a few of the individuals that contributed their assistance to the research for this report. The personnel and staff of the Institute of Texan Cultures, the Library of the Daughters of the Republic of Texas, and the history section of the San Antonio Public Library were, as always, extremely helpful in making their resources available to the search for information on the individuals concerned with the property under study. A very special thanks to the Bexar County Archivist, John Ogden Leal, for his efforts in searching out obscure facts and maps buried within the mass of information under his charge. Dora Guerra, Special Collections at the John Peace Library of the University of Texas at San Antonio, was more than kind to open a vast section of information that is not yet catalogued. Finally, my thanks to Pat Osborne, San Antonio Historical Preservation Officer, for her assistance and ever present personal interest in all of the historic resources of our city. 
. 


\section{INTRODUCTION}

In 1991, the Center for Archaeological Research (CAR), The University of Texas at San Antonio (UTSA), entered into a contract with the Texas Trust Savings Bank of Marble Falls, Texas, to conduct an archival research study on 8.659 acres of unimproved land out of New City Block (NCB) 7657 in southeast San Antonio. The property is located to the south of Mission San José at the northeast corner of the intersection of Mission Road and Southeast Military Drive (Fig. 1). The property is within the Mission Parkway Historic/Archeological District. The project was conducted under the general supervision of Jack D. Eaton, CAR Acting Director and all research was accomplished by Research Associate, I. Waynne Cox. All files and drawing are curated at the CAR-UTSA.

\section{PREVIOUS ARCHAEOLOGICAL RESEARCH}

There have been several archival and archaeological investigations directed toward Mission San José y San Miguel de Aguayo, 41 BX 3, and its acequia system, 41 BX 267 (Fox 1970, Schuetz 1970, Clark 1978, Henderson and Clark 1984). The establishment of the Mission Parkway prompted a thorough archival investigation and survey of the area by the Texas Historical Commission (Scurlock, Benavides, Isham and Clark 1976). At the time of that survey, the Pyron House was still standing and was assigned a Texas State Trimomial site designation, 41 BX 279 (ibid 107-112). Since that report the structure has been demolished. Other investigations have examined the route of the San José acequia and the labores of the mission (Cox 1988, 1989, Fox and Cox 1990, 1991).

\section{HISTORICAL BACKGROUND}

Mission San José y San Miguel de Aguayo was established on March 13, 1720 by Captain Juan Valdéz, accompanied by Father Margil and an official party, on the eastern bank of the San Antonio River "a little more than three leagues" from Mission San Antonio de Valero, measured along its meanders (Valdéz 1720). In approximately 1729, the mission was relocated to its third, and present, site and the course of the acequia, or irrigation system, was established (Habig 1968:88, Cox 1988:1). The farmlands, or labores, of the mission were thus established between the San Antonio River, on the east, and the acequia on the west. The acequia originated at a dam on the river a short distance below the mouth of San Pedro Creek, approximately two miles above the present mission, followed the contours of the terrain along Mission Road and returned to the river just above the dam for the Espada Acequia. In 1777, the farm land was described in a portion of an inspection report (Morfi 1777:211):

The farm occupies an area of about a league $21 / 2$ miles square (4428.4 acres) and is all fenced, the fence being in good condition. For its benefit, water is taken from the San Antonio River and distributed by means of a beautiful irrigation ditch to all parts of the field where corn, beans, lentils, cotton, sugar cane, watermelons, melons, and sweet potatoes are raised.

Upon secularization of the missions in 1793 , the lands were divided into suertes and distributed to the mission Indians and other citizens of the Villa de Béjar. Final distribution of the lands was ordered by the National Congress of the Mexican Republic on September 15, 1823 (León 1823:124). Among the twenty-five grantees receiving lands, four suertes were awarded to Juan Veramendi (Almazraz 1989:41).

Juan Martin del Carmen Veramendi, the second son of Fernando and Maria Josefa Granado de Veramendi, was born in San Fernando de Bexar, now San Antonio, on December 17, 1778. He married Josefa Ruiz de Navarro; they became the parents of at least nine children (Chabot 1937:243-44, San Fernando Baptismal Records, San Fernando Marriage Records). He served as alcalde of Bexar in 1824 and 1825, and in 1830 was elected vice-governor of Coahuila and Texas (Webb 1952 Vol II:837). Their eldest daughter, Maria Ursula Frutuosa (born October 6, 1811) married James Bowie, of Alamo fame, April 25, 1831 (San Fernando Baptismal Records, Marriage Records JPL). Bowie and Veramendi formed a partnership to establish cotton mills in Saltillo, with Veramendi overseeing the Coahuila operation. Upon the death of José Maria Letona, in 1832, Veramendi assumed the office of governor. In September of 1833, while in Monclova, Juan, Josefa, 


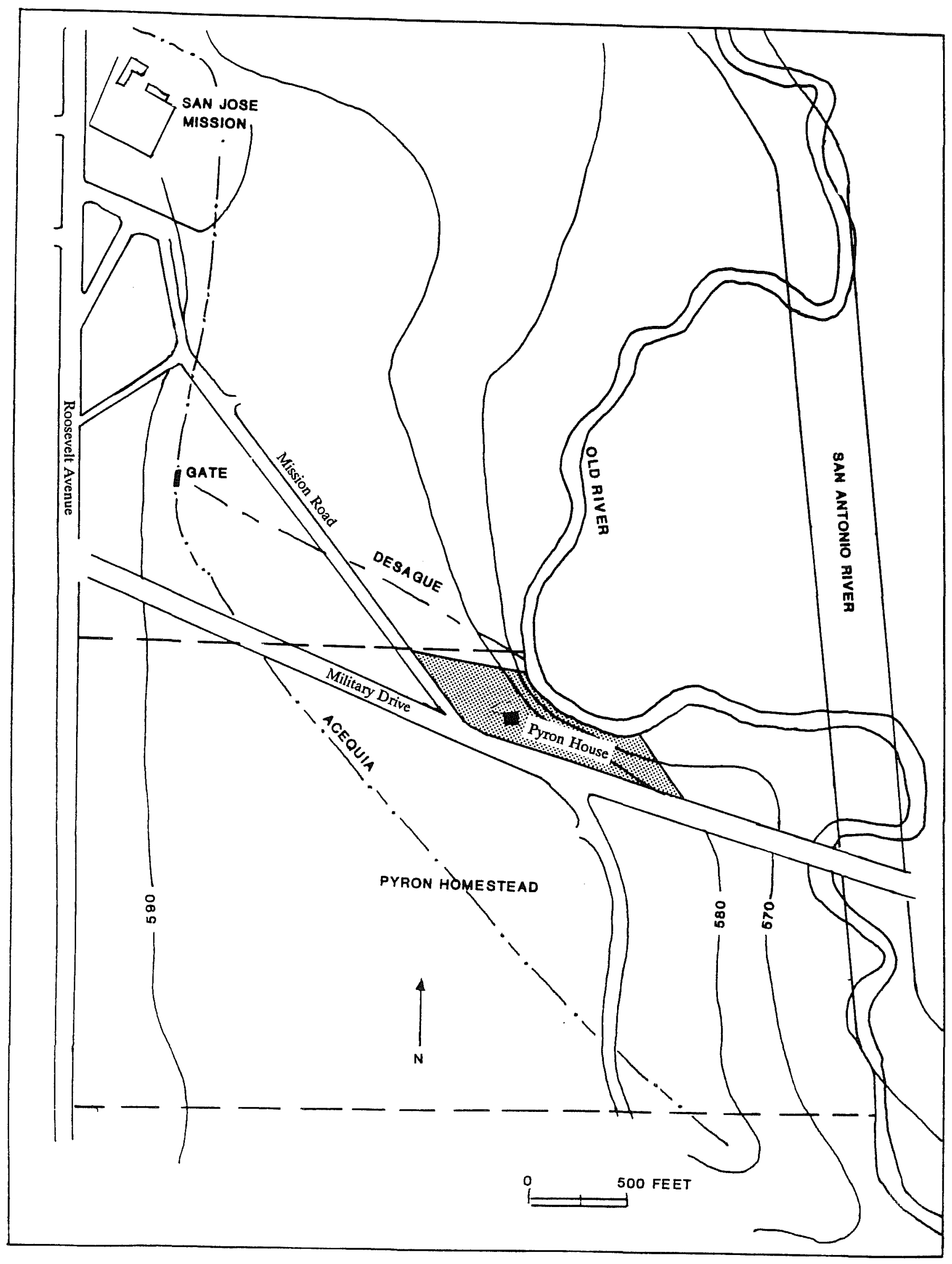

Figure 1. Location of the Pyron Homestead and the San Jose Acequia. 
and Ursula, contracted cholera during an epidemic in that city. They died within three days of each other (Spanish Archives, Burial Records). Since Veramendi died intestate, his estate, with a value of 33,005 pesos, 2 reals, and 7 granos, was probated by the court of Acale Manuel Ximenez. His property passed to his children, with Luciano Navarro appointed guardian for the minor children (Spanish Archives, Wills 117c). A daughter, Maria Josefa de la Concepción Gregoria, married Rafael Garza on December 1, 1838, and after her death he married her younger sister, Maria Antonia, on October 11, 1846 (Marriage Records JPL, Chabot 1937:224, Spanish Archives, Marriage Records:450). The mission properties were acquired jointly, by a son, José Marco Veramendi, and Maria Antonia Veramendi e Garza and her husband, Rafael C. In 1848, five suertes of the mission lands were purchased by William Ouny and Charles Pyron ( $B C D R$ G1:374). William Sanders Oury was born in Abingdon, Virginia, on August 13, 1817, and arrived in Texas in 1833. He served with the Texas Army in San Antonio and was dispatched from the Alamo with a message to Sam Houston in February of 1836. He was captured during the ill-fated Mier Expedition and participated in the attempted escape near Saltillo in 1843. Oury served in the Texas Rangers under John Coffee Hays and the Texas Mounted Rangers and the Texas Mounted Volunteers during the Mexican War (San Antonio Express 1930; Webb 1952 Vol.II:320). He returned to San Antonio following the war and entered into partnership with Charles Pyron.

Charles Lynn Pyron (Fig. 2) was born in Marion County, Alabama, in approximately 1819, and was educated in the normal schools of the state. He is reputed to have served in the Mexican War under Generals Scott and Taylor (Kilstofte 1948:1). It is possible that he became acquainted with Oury during that period. At any rate, by 1848 , he was residing in Port Lavaca, Texas, where he met his future wife, Octavia Caroline Smith, formerly of South Carolina. In August of that year, he and Oury purchased the Veramendi lands, about two hundred acres, for $\$ 1100$ ( $B C D R$ G1:374). He probably contracted for construction of the house at that time, for after the purchase of the ranch, he returned to Port Lavaca and married Octavia on November 15, 1849 (Branda 1976 Vol. III:763). In 1849, William Oury married Inez Garcia, and on April 9, 1850, granted a power of attorney to Pyron to act as his agent for their real estate and joint stock holdings and departed for California ( $B C D R$ K2:631, Webb Vol II:320). Pyron also purchased 553 1/2 acres to the west of the acequia from the Manuel Leal grant of a league and labor acquired by William P. Delmour in November of 1853 ( $B C D R$ P1:201). He apparently began an expansion of his holding in both land and stock during this period and by 1859 was forced to declare bankruptcy, which plagued his estate for a number of years $(B C D R$ $\mathrm{H} 2: 652$, S1:580, 16:297).

With the onset of the Civil War, Pyron raised a company of troops into state service in April of 1861, which was mustered into the Confederate Army on May 23, 1861, as Company B, 2nd Texas Mounted Rifles. He served as a Major and battalion commander under General Henry Sibley in the New Mexico campaign. His advance precipitated the battle of Valverde on February 21, 1862, and his unit played a prominent role in the battle of Glorieta Pass on March 28. After the defeat of the Confederate forces in New Mexico, he was elected colonel of the 2nd Texas Cavalry and participated in the Teche campaign, and was wounded at Lafourche Crossing on June 21, 1863. He returned to San Antonio, and on April 16 assumed command of the post, and in June was placed in charge of the Western Sub-District of Texas. After the war, he returned to San Antonio and died of a lingering case of consumption (tuberculosis) on August 24, 1869 (Branda 1976 Vol. III:763; Davis and Grobe 1929: 1906: San Antonio Herald 1869:3).

Upon Charles Pyron's death the estate passed to his widow, Octavia Caroline, and their children, Clara Albertine, Charles Jackson, Ellen, and Madison L., ranging in age from 18 to 10 (Davis and Grobe 1929: 1906, USDI-OC 1860). The family continued to hold the homestead property for the next two generations. In 1881, a final lawsuit resulting from the bankruptcy was settled awarding a portion of the original ranch, to the north of the homestead property, to Samual G. French (Bexar County Archives, Pyron Folder \# 456).

The San José acequia, which flowed through the middle of the homestead tract was still operating and, in 1886, a suit was brought by Charles Dignowity against Octavia Pyron to allow a survey along the route to allow the cleaning and dredging of the ditch to a width of nine feet $(B C D R$ 53:32). In 1894, the acequia was reopened under the Texas Water Act of 1889, at that time described as "four feet deep and 12 feet wide and the carrying capacity thereof shall be 100 cubic feet per second" (Water Board Records Vol.1 August 10, 1894:4). 


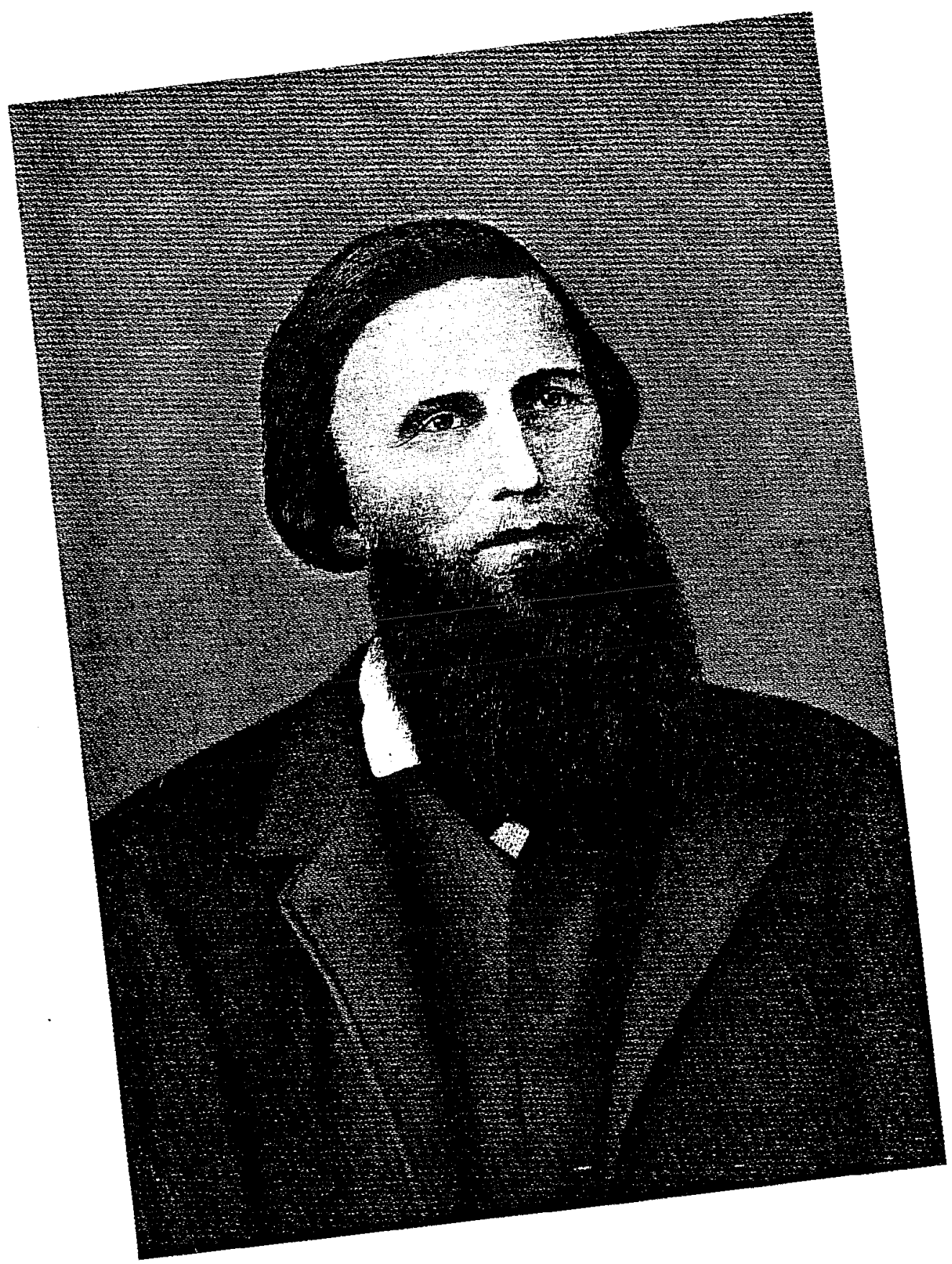

bot, Gharles. Pyrow

Figure 2. Charles Lymn Pyron

4 
The family moved into San Antonio in 1905, but continued to hold the homestead (Kilstofte 1948:2). Madison L. Pyron became a dentist and moved his residence and practice to Boerne after 1904. Charles Pyron continued to farm the homestead and Octavia resided at 1021 South Alamo and retained ownership of 139 acres of the property. In 1911, the heirs granted the county right-of-way on the property to pave the "new" Mission Road (BCDR 362:599). On Christmas day of 1913, Charles Pyron died after a lengthy illness and his share passed to his widow, Ellen (San Antonio Express 1913). On June the 2nd, 1914, Octavia Pyron died at her home on Alamo Street, survived by Madison, Clara, daughter-in-law Ellen, and two grandchildren (San Antonio Express 1914).

In 1942 a hurricane severely damaged the house and it was repaired and rented as a residence. In 1964, the structure was occupied as the B and C Auto Parts, then known as 1435 Southeast Military Drive, and served as the residence for the manager, Anthony Pawlik, and his wife Patsy (Polk 1964). The business occupied the building until 1974 when it became vacant and remained so until its destruction (Polk 1974). Ellen Pyron died in May of 1965, and was entered with her family in the Confederate Cemetery in San Antonio (San Antonio Light 1965).

\section{CONCLUSIONS AND RECOMMENDATIONS}

In attempting to reconstruct the history of the site several considerations were addressed, primary among these were the probability of any structural remains that might be encountered during future development of the site, and the location of the buried remains of the San José acequia. The archives failed to reveal any evidence of construction during the mission period or immediately after the secularization. While it is possible that structures existed during the Veramendi ownership, this is highly unlikely due to the very limited use of the land during this period.

The first structure on the site was undoubtedly the Pyron House. Since he and Oury purchased the property in August of 1848, and Pyron returned to San Antonio with his bride after November of 1849 , it is most likely that the home was constructed during that period. The structure is clearly indicated on several maps in its known location dating until after 1973 (USGS 1967). The San Antonio City Directories indicated that the structure, although vacant, was still standing in 1990 (Polk 1984-1990). Although the structure has been destroyed the foundation remains intact at, or just below, ground level.

The second consideration, the location of the San José acequia, was resolved by a plat submitted as evidence to the Bexar County District Court in September of 1881 (Bexar County Archives, Pyron Folder \#456). By replotting the metes and bounds calls from that survey on to the modern street pattern, the acequia can clearly be established as being located to the west of the property under consideration (Fig. 1).

Therefore, it appears that the primary consideration regarding the future development rest with the buried remains of the Pyron House. If further disturbance of the site is anticipated the exposed remains of the structure should be recorded and limited sub-surface excavations should be considered. Due to standard site utilization of the period, further support structures, for example a detached kitchen facility, may well be encountered. The Pyron House was important both as a representative structure of the period and in connection with a historical individual of Texas history. It is regrettable that the structure was destroyed prior to proper investigation, yet enough remains to indicate that future work could contribute valuable information of the occupation period of the site. 


\section{REFERENCES CITED}

Almaraz, F. D. Jr.

1989 The San Antonio Missions and their System of Land Tenure. University of Texas Press, Austin.

Bexar County Courthouse, San Antonio

Bexar County Archives

Burial Records of Church of Monclova, Mexico 1833

File Folders

San Fernando Baptismal Records, translator J. O. Leal

San Fernando Marriage Records, translator J. O. Leal

Spanish Records, Three Volumes

Spanish Wills, Works Projects Administration translations

Water Board Records

Bexar County Deed Records

Bexar County Probate Records

Branda, E. S.

1976 The Handbook of Texas: A Supplement. Texas State Historical Association, Austin.

Chabot, F.

1937 With the Makers of San Antonio. Privately Published, San Antonio.

Clark, J. W. Jr.

1978 Mission San José y San Miguel de Aguayo Archeological Investigations, December 1974. Texas Historical Commission, Office of the State Archeologist, Report 29.

Cox, I. W.

1988 Archaeological Monitoring of the San José Acequia (41 BX 267), Wastewater Facilities Improvements Program, San Antonio, Texas. Center for Archaeological Research, The University of Texas at San Antonio, Archaeological Survey Report No. 175. 
1989 Archaeological Survey and Testing for Mission County Park, San Antonio, Bexar County, Texas. Center for Archaeological Research, The University of Texas at San Antonio, Archaeological Survey Report No. 190.

Davis, E. A. and E. H. Grobe (editors)

1929 New Encyclopedia of Texas. Six Volumes. Texas Development Bureau, Dallas.

Fox, A. A and I. W. Cox

1990 Archaeological Monitoring in Connection with the San Antonio Wastewater Facilities Improvement Program, San Antonio, Bexar County, Texas. Center for Archaeological Research, The University of Texas at San Antonio, Archaeological Survey Report No. 194.

1991 Testing of the San José Mission Acequia, San Antonio Missions National Historical Park, Bexar County, Texas. Center for Archaeological Research, The University of Texas at San Antonio, Archaeological Survey Report No. 207.

Fox, D. E.

1970 Archeological Salvage at San José, December 1969, April and August 1970. Office of the State Archeologist, Special Report 3, Texas Historical Survey Committee Austin

Habig, M. A.

1968 The Alamo Chain of Missions, A History of San Antonio's Five Old Missions. Franciscan Herald Press, Chicago, Illinois.

Henderson, J. and J. W. Clark, Jr.

1984 The Acequia and Other Features at Mission San José, Bexar County, Texas. Texas State Department of Highways and Public Transportation Division, Publications in Archaeology Report No. 25.

John Peace Library, The University of Texas at San Antonio

Special Collection

List of Marriages Recorded in the Catholic Church from 1778-1841. Stewart Title Collection.

Kilstofte, J.

1948 Homestead's Centennial. San Antonio Express Magazine, September 26, 1948, San Antonio.

Leon, Fr. D. de

1823 Fr. Diaz de Leon to Jefe Politico José Antonio Saucedo, November 21, 1823. In the San Jose Papers, Part III. Translated by Fr. B. Leutenegger, editor Sister C. Casso, Old Spanish Missions Historical Research Library at Our Lady of the Lake University, 1990, San Antonio. 
Morfi, Fr. J. A. de

1777 Fr. Juan Agustin Morfi's Report on Mission San José, Dec., 1777. In The San José Papers: The Primary Sources for the History of San José y San Miguel de Aguayo from its Founding in 1720 to the Present. Part I: 1719-1791. Translated by Fr. B. Leutenegger. Compiled and annotated by Fr. M. A. Habig. Old Spanish Missions Historical Research Library at San José Mission, Our Lady of the Lake University, San Antonio.

Polk, R. L.

1964 Polk's San Antonio City Directory. R. L. Polk and Company Publishers, Dallas.

1974 Polk's San Antonio City Directory. R. L. Polk and Company Publishers, Dallas.

1984-85 Polk's San Antonio City Directory. R. L. Polk and Company Publisher, Dallas.

1990 Polk's San Antonio City Directory. R. L. Polk and Company Publishers, Dallas.

San Antonio Express

1913 Death Notices. December 25.

1914 An Old Resident is Dead. June 3.

1930 Adventures of Texas Fighter, including Flight from Alamo with message, recalled by Kin, October 20.

San Antonio Herald

1869 Col. Pyron dead, 26 August.

San Antonio Light

1965 Final Rites For Pioneer Woman Set, May 29.

Schuetz, M. K.

1970 Excavation of a section of the Acequia Madre in Bexar County, Texas, and Archeological Investigations at Mission San José in April 1968. Texas Historical Survey Commission, Archeological Report 19.

Scurlock, D., A. Benavides, Jr, D. Isham and J. W. Clark, Jr.

1976 An Archeological and Historical Survey of the Proposed Missions Parkway, San Antonio, Texas. Office of the State Archeologist, Texas Historical Commission Report No. 17.

United States Department of the Interior Geological Survey (USGS)

1967 Southton Quadrangle. Photo revised to 1973 United States Department of the Interior, Office of the Census (USDI-OC).

1860 The Eight Population Census, 1860. Bexar County, Texas. 
Valdez, J.

1720 Report of Captain Juan Valdez, March 13, 1720. In The San José Papers, Part I:1719-1791, Fr. B. Leutenegger, translator: Fr. M. A. Habig, compiler and annotator. Old Spanish Missions Historic Research Library at San Jose Mission, San Antonio, 1978.

Webb, W.P.,editor

1952 The Handbook of Texas. Two volumes. Texas State Historical Association, Austin. 




